\title{
Interim report on drug utilization review of community acquired, nursing home acquired and nosocomial pneumonia: Clinical, bacteriological and radiological spectrum
}

CW ChOW MD, N SENATHIRAGAH MBBS, M RAWJI, M CHAN, LR LEE-PACK, CK ChAN MD FRCPC FCCP FACP

CW Chow, N Senathiragah, M Rawj, M Chan, LR LeE-PACK, CK Chan. Interim report on drug utilization review of community acquired, nursing home acquired and nosocomial pneumonia: Clinical, bacteriological and radiological spectrum. Can J Infect Dis 1994;5(Suppl C):20C-27C.

OBлectrves: To review the epidemiology of community acquired, nursing home acquired and nosocomial pneumonia in terms of clinical, bacteriological and radiological features and to examine the spectrum of and response to antimicrobial agents used in its management.

Design: A retrospective review of all hospital records with pneumonia coded in the discharge diagnoses over a five-year period from April 1987 to March 1993.

Setring: University-affiliated, community-based hospital with a mixed primary to tertiary referral base. Patient Selection: Patients included in the study were all patients with a diagnosis of pneumonia as identified by computer records of diagnostic codes of all discharges; patients with a specific diagnosis of Pneumocystis carinii pneumonia were excluded. One thousand seven hundred and eighty-two patients out of 74,435 discharges over the five-year period met the inclusion criteria.

Results: The initial 1300 of the 1782 cases of pneumonia are included in this interim report. Mean age was 65 years (range 16 to 103) with $60 \%$ men and $40 \%$ women. Sixty-two per cent of all cases were community acquired, $29 \%$ were hospital acquired and 9\% were nursing home acquired. One thousand two hundred and sixty (97\%) patients had at least one concomitant medical condition, mainly cardiac disease, alcoholism and chronic obstructive lung disease. Chest roentgenogram was abnormal in 98\%. Cultures of sputum, bronchoalveolar lavage fluid, blood and/or serology revealed positive results in 785. The most common pathogens were Streptococcus pneumoniae (154), Haemophilus influenzae (147), Staphylococcus aureus (111) and Pseudomonas aeruginosa (100). In the group with community acquired pneumonia, S pneumoniae and $H$ influenzae predominated. In the hospital acquired pneumonia group $\mathrm{S}$ aureus and $P$ aeruginosa were more common, although $S$ pneumoniae remains a significant pathogen. In the nursing home acquired pneumonia group, Gram-negative agents were the most common. The pattern of antimicrobial agents used, usually begun empirically when culture results are pending, showed that the majority of patients was treated with combination antibiotics for both Gram-positive and Gram-negative coverage. Ceftriaxone was usually prescribed with either erythromycin or clindamycin. In about half the patients, the ceftriaxone dose was $1 \mathrm{~g}$ per day. Ninety-six (7\%) patients developed complications of pneumonia and 207 (16\%) patients required intensive care unit admission. Nine hundred and fifty-nine (73\%) patients were cured or improved at time of discharge, 21 (1.5\%) patients discharged themselves against medical advice and $320(25 \%)$ patients died during admission to hospital, of whom 165 cases had pneumonia listed as a cause on the death certificate. 
Conclusions: Pneumonia remains a significant illness with high morbidity and mortality. Those affected and requiring hospitalization are elderly and ill. The most common pathogens overall continue to be $S$ preumoniae and $H$ influenzae, although Gram-negative organisms and $S$ aureus were also significant agents in nosocomial and nursing home acquired pneumonia. The high percentage of Gram-negative infections in the community acquired group has not been previously described and may represent a change in the pattern of pathogens affecting this group. Three of the 53 community acquired cases in whom Paeruginosa was implicated were detected on blood cultures and were definitely pathogens. Ten of the 53 patients had underlying bronchiectasis or cystic fibrosis and one patient had a history of hematogenous malignancy. Whether the finding of $P$ aeruginosa represents true pathogenicity or colonization in the 53 cases is difficult to differentiate in a retrospective fashion. However, all but two received antibiotic therapy, and 10 of the 40 survivors in this subgroup received adequate coverage for pseudomonas. Although yield from routine investigations is only $60 \%$ (785 of 1300 patients in this study), cultures of blood and sputum should be sent in all patients as it may help to narrow choice of antimicrobial agents and aid in oral step-down selection. Only in select patients should serum serology and more costly and invasive procedures such as bronchoscopy and thoracocentesis be done. It appears that the current pattern of antimicrobial use is appropriate for management of pneumonia given the pattern of offending organisms seen. In the present study. pragmatic use of ceftriaxone at $1 \mathrm{~g} / 24 \mathrm{~h}$ in these sick patients appeared to result in a therapeutic outcome similar to other antibiotic combination therapy.

Key Words: Community acquired pneumonia, Drug utilization review, Hospital acquired pneumonia, Nursing home acquired pneumonia

\section{Rapport intérimaire de revue d'emploi des médicaments dans les pneumonies extra-hospitalières, acquises en foyer et nosocomiales : spectre clinique, bactériologique et radiologique.}

OBJECTIFs : Passer en revue les paramètres épidémiologiques relatifs à la pneumonie extra-hospitalière, acquise en foyer et nosocomiale en termes de caractéristiques cliniques, bactériologiques et radiologiques afin d'examiner le spectre des agents antimicrobiens utilisés dans leur traitement et les résultats.

MoDĖLe : Revue rétrospective de tous les dossiers hospitaliers où figurait le code "pneumonie", comme diagnostic au moment du congé, sur une période de cinq ans s'échelonnant d'avril 1987 à mars 1993.

Contexte : Hôpital communautaire affilié à un établissement universitaire, avec base de références mixte, de primaires à tertiaires.

Sélection Des Patients : Les patients admis au sein de l'étude étaient tous porteurs d'une pneumonie identifiée par les codes de diagnostic dans les dossiers informatisés, au moment des congés. Les patients porteurs de diagnostics précis de pneumonie à Pneumocystis carinii ont été exclus. Mille sept cent quatre-vingt-deux patients des 74435 congés donnés sur la période de cinq ans répondaient aux critères d'inclusion.

RÉsultats : Les 1300 premiers de ces 1782 cas de pneumonie ont été inclus dans ce rapport intérimaire. La moyenne d'âge était de 65 ans (variation 16 à 103), 60 \% étaient des hommes et $40 \%$ des femmes. Soixante-deux pour cent de tous les cas avaient été acquis au sein de la communauté, $29 \%$ dans un hôpital et $9 \%$ dans un foyer. Mille deux cent soixante patients (97\%) présentaient au moins un problème de santé concomitant. principalement la maladie cardiaque, lalcoolisme et la maladie pulmonaire obstructive chronique. La radiographie pulmonaire était anormale chez $98 \%$. Les cultures dexpectorations, le liquide de lavage broncho-alvéolaire et les analyses sanguines et/ou sérologiques ont donné des résultats positifs chez 785 patients. Les pathogènes les plus fréquents ont été Streptococcus pneumoniae (154). Haemophilus influenzae (147). Staphylococcus aureus (111) et Pseudomonas aeruginosa (100). Dans le groupe atteint de pneumonie extra-hospitalière, S. pneumoniae et $H$. influenzae prédominaient. Dans le groupe atteint de pneumonie acquise dans un hôpital, S. aureus et $P$. aeruginosa étaient les plus fréquents. bien que S. pneumoniae soit demeurê un pathogène important. Dans le groupe des pneumonies acquises en foyer, les agents Gram négatifs étaient les plus fréquents. L'antibiothẻrapie utilisée commencée habituellement empiriquement lorsque les résultats de cultures étaient attendus, a révélé que la majorité des patients ont été traité par une antibiothérapie qui visait une couverture à la fois Gram positive et Gram négative. Le ceftriaxone a habituellement été prescrit avec soit de l'érythromycine ou de la clindamycine. Chez environ la moitié des patients, le ceftriaxone a été administré à raison d'un gramme par jour. Quatre-vingtseize patients ( $7 \%$ ) ont présenté des complications de leur pneumonie et 207 (16\%) ont nécessité des soins intensifs. Neuf cent cinquante-neuf patients $(73 \%)$ ont été guéris ou leur état était amélioré au moment de leur congé. Vingt-et-un patients (1,5\%) ont mis fin à leur traitement contre l'avis médical et 320 (25\%) sont décédés durant leur hospitalisation, dont 165 portaient la mention de pneumonie comme cause du décès au certificat de décès. Conclusions : La pneumonie demeure une maladie grave qui s'accompagne de taux de morbidité et de mortalité élevés. Ceux qui en souffrent et qui requièrent une hospitalisation sont âgés et gravement malades. Les pathogènes les plus fréquents en général sont toujours $S$. pneumoniae et $H$. influenzae, bien que les organismes à Gram négatif et $\mathrm{S}$. aureus aient également été largement représentés dans les cas de pneumonie nosocomiale et acquise en foyer. Le pourcentage élevé d’infection Gram négative dans le groupe de pneumonie extra-hospitalière n'a pas été décrit précédemment et pourrait représenter un changement dans l'expression des pathogènes qui affectent ce groupe. Trois des 53 cas de pneumonie extra-hospitalière, chez qui $P$. aeruginosa avait été identifié, ont été diagnostiqués à l'aide d'hémocultures et confirmés; 10 des 53 patients présentaient une bronchiectasie sousjacente ou une fibrose kystique et un des patients avait des antécédents de cancer hématogène. Il est difficile de différencier rétrospectivement entre la présence de $P$. aeruginosa à titre de pathogénicitẻ vraie ou de colonisation chez ces 53 cas. Toutefois, sauf deux, ils ont tous reçu une antibiothérapie et 10 des 40 survivants de ce sous-groupe ont reçu une couverture adéquate contre les Pseudomonas. Bien que les analyses de routine n'aient 


\begin{abstract}
donné que $60 \%$ (785 des 1300 patients dans cette étude), des hémocultures et des cultures d'expectorations devraient être obtenues chez tous les patients, puisqu'elles aident à restreindre le choix d'antimicrobiens et contribuent à la sélection d'une antibiothérapie séquentielle. Seulement chez des patients sélectionnés doit-on recourir à des analyses sérologiques et à des interventions plus coûteuses et effractives, comme la bronchoscopie ou la thoracocentèse. Il semble que le mode actuel de traitement antimicrobien soit approprié pour traiter la pneumonie, compte tenu du fonctionnement des pathogènes en cause. Dans la présente étude, l'emploi pragmatique de ceftriaxone à raison de $1 \mathrm{~g} / 24 \mathrm{~h}$ chez ces malades a semblé donner des résultats thérapeutiques semblables à ceux d'autres traitements d'association.
\end{abstract}

$\mathrm{D}$ ESPITE THE ADVENT OF EFFECTIVE ANTIMICROBIAL AGENTS and increasingly better understanding of the pathogenesis and etiology of pneumonia, morbidity and mortality remain high. Accurate assessment of the overall burden of pneumonia on health care cannot be ascertained because a significant percentage of pneumonia is managed on an out-patient basis. However, statistics from the United States suggest that over 3.3 million cases of community acquired pneumonia (CAP) occur annually (1). Although mortality is low in the out-patient setting, it is the fifth leading cause in those over 65 years of age in the United States (2). Mortality is usually $25 \%$ in those requiring hospitalization, with highest mortality in cases where intensive care unit (ICU) admission is required (3-10). In one study of 30 patients with pneumonia treated in the ICU, mortality was found to be as high as $47 \%$ (11). In most reports, higher morbidity and mortality were seen in the elderly $(5,7,12)$, and in those with concurrent illnesses such as chronic obstructive lung disease, diabetes mellitus, chronic renal failure, congestive heart failure and chronic alcohol abuse (5,7-9). Our current ability to improve longevity allows patients to develop concomitant medical illnesses and is likely responsible for the lack of significant improvement in the overall prognosis of pneumonia. In the past decade, there has been an increase in the pool of susceptible hosts, particularly patients with compromised immune defence systems. During this period, there has been a marked increase in human immunodeficiency virus disease and an increase in numbers of survivors of organ transplantation who are on chronic immunosuppressive agents. At the same time, the development of newer and more powerful antimicrobial agents has met with a parallel emergence of resistant and new strains of infecting organisms.

Recent publication of guidelines for the management of CAP (13-15) underscores the importance of continually updating our knowledge of this persistent but everchanging disease. The current study was undertaken to review the contemporary epidemiology of CAP, nursing home acquired pneumonia (NHAP) and nosocomial or hospital acquired pneumonia (HAP) in a mixed primary to tertiary setting. We sought to characterize the patient population at risk, the spectrum of clinical and roentgenographic presentation, the pattern of offending pathogens and the response to current pragmatic antimicrobial regimens used in the management of pneumonia in the hospital setting.

\section{PATIENTS AND METHODS}

Sample population: All patients with a diagnosis of pneumonia identified by a computer database of all discharges from the Wellesley Hospital, Toronto, Ontario were selected from a retrospective review of hospital charts spanning the five-year period from April 1987 to March 1992. The Wellesley Hospital is a universitybased, 400-bed hospital that functions mostly as a primary and secondary centre with annual total hospital patient discharge of 15,000 to 16,000 . A small portion of discharges originates from a tertiary referral base due to proximity to The Princess Margaret Hospital, the major oncology referral hospital in southern Ontario, and to the existence in our hospital of the only burn unit in the city. Patients with a diagnosis of Pneumocystis carinii pneumonia were excluded from the study.

Data collection: Information was manually extracted from the charts and recorded on a database sheet before final entry into a computer database program. Information gathered included: first, patient demographics such as age and sex; second, concurrent medical illnesses (defined as chronic obstructive pulomary disease, asthma, past and present smoking history, diabetes mellitus, chronic renal disease, congestive heart disease, underlying malignancy, immune deficiency - both primary and iatrogenic, such as long term use of immunosuppressive agents - and chronic alcohol abuse); third, laboratory findings including complete blood cell count, serum sodium, chest roentgenogram (in the majority of cases, the official radiology report was used although at times only results of the handwritten chart were reliable) and microbiological tests; fourth, duration and type of antimicrobial agents used and presence of adverse drug reactions; fifth, development of complications (defined as lung abscess, empyema. pleural effusion, congestive heart failure, bacteremia and pneumothorax); sixth, need for oxygen therapy and ICU admission; seventh, length of stay in hospital and in the ICU; and finally, ultimate outcome (see below).

Pneumonia was considered to be community acquired if the diagnosis was made within the first $72 \mathrm{~h}$ of admission, hospital acquired if made after $72 \mathrm{~h}$ and nursing home acquired if the patient was a resident of a nursing home and the diagnosis was made within the first $72 \mathrm{~h}$.

Microbiological data: All microbiological data were extracted from the official microbiology department 
TABLE 1

Total pneumonia cases during fiscal years 1987 to 1992

\begin{tabular}{|c|c|c|c|c|c|}
\hline Fiscal year & $\begin{array}{l}\text { Total pneumonia } \\
\text { cases }\end{array}$ & $\begin{array}{l}\text { Pneumonia cases } \\
\text { among total } \\
\text { discharged (\%) }\end{array}$ & $\begin{array}{l}\text { Average length of } \\
\text { stay of pneumonia } \\
\text { cases (days) }\end{array}$ & Total discharges & $\begin{array}{l}\text { Average length of } \\
\text { stay overall (days) }\end{array}$ \\
\hline April 1987 - March 1988 & 349 & 2.1 & 27 & 16,263 & 11 \\
\hline April 1988 - March 1989 & 312 & 2.0 & 20 & 15,287 & 10 \\
\hline April 1989 - March 1990 & 298 & 2.0 & 26 & 15,201 & 9 \\
\hline April 1990 - March 1991 & 375 & 2.7 & 24 & 13,765 & 9 \\
\hline April 1991 - March 1992 & 448 & 3.2 & 24 & 13,919 & 9 \\
\hline Total cases & 1782 & 2.4 & 24 & 74,435 & 9 \\
\hline
\end{tabular}

laboratory report form. Although investigations were not standardized for each case of pneumonia, standard clinical practice at the Wellesley Hospital for the workup of pneumonia included: sputum for Gram stain, culture and sensitivity; and blood for aerobic and anaerobic cultures. All specimens were processed through the microbiology department at the Wellesley Hospital. Blood cultures were performed using Bactec (BectonDickinson, Maryland) bottles, and sputum samples were handled in the standard microbiological laboratory fashion. Tests for atypical agents such as Legionella species and mycobacteria, serum serology, thoracocentesis, percutaneous needle aspiration and bronchoscopy with bronchoalveolar lavage with or without protected brush were done only on selected patients, at the discretion of the attending and/or the consulting physicians. When ordered, testing for legionella was performed by the direct fluorescent antibody method, followed by culture. Mycobacteria were investigated initially with acid-fast stain and fluorescent antibody stain followed by cultures at the Province of Ontario Health Ministry's Mycobacterial Laboratories. Mycoplasma pneumoniae was examined with acute and convalescent antibody titres.

Outcome measurements: Patients were considered to have improved or be cured if they were alive and off antibiotics at the end of the hospitalization period. Those who discharged themselves against medical advice were included in the 'improved' group as it can be assumed that they were alive at time of discharge. Death certificates of those who died during the hospital stay were reviewed. If the death certificate listed pneumonia as a cause of death, the patient was considered to be a pneumonia death. Need of oxygen therapy, ICU admission and development of complications of pneumonia as defined above were also recorded.

\section{RESULTS}

During the five-year period (April 1987 through March 1992), there were 74,435 patient discharges from the Wellesley Hospital. One thousand seven hundred and eighty-two cases (2.6\% of all discharges) had a diagnosis of pneumonia. The first 1300 of the 1782 cases identified are reported (Table 1).
TABLE 2

Characteristics of patients admitted to hospital with pneumonia

\begin{tabular}{|c|c|c|c|}
\hline & CAP & NHAP & HAP \\
\hline $\begin{array}{l}\text { Total number } \\
\text { Male } \\
\text { Female }\end{array}$ & $\begin{array}{c}806(62 \%) \\
489 \\
317\end{array}$ & $\begin{array}{c}116(9 \%) \\
72 \\
44\end{array}$ & $\begin{array}{c}378(29 \%) \\
223 \\
155\end{array}$ \\
\hline $\begin{array}{l}\text { Age: Male } \\
\text { Female }\end{array}$ & $\begin{array}{l}62 \\
66\end{array}$ & $\begin{array}{l}78 \\
84\end{array}$ & $\begin{array}{l}63 \\
67\end{array}$ \\
\hline $\begin{array}{l}\text { Average length } \\
\text { of stay (days) } \\
\text { Male } \\
\text { Female }\end{array}$ & $\begin{array}{l}17 \\
16 \\
20\end{array}$ & $\begin{array}{l}18 \\
20 \\
15\end{array}$ & $\begin{array}{l}42 \\
45 \\
38\end{array}$ \\
\hline $\begin{array}{l}\text { Number of } \\
\text { patients } \\
\text { requiring ICU }\end{array}$ & 101 & 3 & 114 \\
\hline $\begin{array}{l}\text { Average length } \\
\text { of ICU stay } \\
\text { (days) }\end{array}$ & 7 & 7 & 8 \\
\hline Male & $\begin{array}{c}7 \\
\text { (60 patients) }\end{array}$ & $\begin{array}{c}3 \\
\text { (1 patient) }\end{array}$ & $\begin{array}{c}8 \\
\text { (64 patients) }\end{array}$ \\
\hline Female & $\begin{array}{c}7 \\
\text { (41 patients) }\end{array}$ & $\begin{array}{c}8 \\
\text { (2 patients) }\end{array}$ & $\begin{array}{c}8 \\
\text { (50 patients) }\end{array}$ \\
\hline $\begin{array}{l}\text { Smoking history } \\
\text { Male } \\
\text { Female }\end{array}$ & $\begin{array}{l}378(47 \%) \\
255(52 \%) \\
123(39 \%)\end{array}$ & $\begin{array}{r}24(21 \%) \\
17(24 \%) \\
7(16 \%)\end{array}$ & $\begin{array}{r}128(34 \%) \\
96(43 \%) \\
32(21 \%)\end{array}$ \\
\hline $\begin{array}{l}\text { Comorbidity } \\
(\geq 1)\end{array}$ & $778(96 \%)$ & $113(97 \%)$ & $369(98 \%)$ \\
\hline No comorbidity & $28(4 \%)$ & $3(3 \%)$ & $9(2 \%)$ \\
\hline Complications & $49(6 \%)$ & $9(8 \%)$ & $38(10 \%)$ \\
\hline $\begin{array}{l}\text { Death } \\
\text { Pneumonia } \\
\text { Not pneumonia }\end{array}$ & $\begin{array}{r}149(18 \%) \\
75(51 \%) \\
74(49 \%)\end{array}$ & $\begin{array}{l}30(26 \%) \\
20(67 \%) \\
10(33 \%)\end{array}$ & $\begin{array}{r}141(37 \%) \\
70(51 \%) \\
71(49 \%)\end{array}$ \\
\hline
\end{tabular}

CAP Community acquired pneumonia; HAP Hospital acquired pneumonia: ICU Intensive care unit: NHAP Nursing home acquired pneumonia

There appears to be a slight preponderance of males (784 cases or $60 \%$ ) compared with females (516 cases or $40 \%$ ). Mean age was 65 years (range 16 to 103). One thousand two hundred and sixty (97\%) had at least one concomitant medical condition as defined at the start of the study; of these patients, the majority had two or more concurrent medical illnesses. Of the 1300 cases of pneumonia, $806(62 \%)$ were CAP, $116(9 \%)$ were NHAP and 378 (29\%) were HAP. The three groups were similar 
TABLE 3

Roentgenographic presentation*

\begin{tabular}{lccc}
\hline & CAP & NHAP & HAP \\
& $n=793$ & $n=114$ & $n=366$ \\
\hline Focal & $515(65 \%)$ & $82(72 \%)$ & $244(67 \%)$ \\
Diffuse & $219(28 \%)$ & $25(22 \%)$ & $95(26 \%)$ \\
Normal & $16(2 \%)$ & $1(1 \%)$ & $9(2 \%)$ \\
Other & $43(5 \%)$ & $6(5 \%)$ & $18(5 \%)$ \\
\hline
\end{tabular}

"Chest roentgenograms were available in 1273 patients; CAP Community acquired pneumonia: HAP Hospital acquired pneumonia: NHAP Nursing home acquired pneumonia

\section{TABLE 4}

Most common pathogens identified from cultures in 1300 patients*

\begin{tabular}{lcccc}
\hline & Total & CAP & NHAP & HAP \\
\hline Streptococcus pneumoniae & 154 & 112 & 7 & 35 \\
Haemophilus influenzae & 147 & 104 & 3 & 40 \\
Staphylococcus aureus & 111 & 58 & 2 & 51 \\
Pseudomonas aeruginosa & 100 & 53 & 6 & 41 \\
Klebsiella pneumoniae & 59 & 27 & 7 & 25 \\
Escherichia coli & 41 & 16 & 6 & 19 \\
Proteus mirabilis & 13 & 4 & 1 & 8 \\
Moraxella catarrhalis & 9 & 6 & 0 & 3 \\
\hline
\end{tabular}

"These results include cultures of sputum, blood, bronchoalveolar lavage and/or protected brush specimens, pleural fluid and serology. CAP Community acquired pneumonia: HAP Hospital acquired pneumonia: NHAP Nursing home acquired pneumonia

in terms of presence of comorbid disease although the patients in the NHAP group were older and fewer had a history of smoking (Table 2).

Chest roentgenogram was done on 1273 (98\%) patients on admission and was abnormal in $98 \%$ of these, although a surprising $2 \%$ of patients with HAP were reported to have a normal chest roentgenogram (Table 3). Focal radiographic abnormalities were most common. Among the three groups of CAP, NHAP and HAP, there was no difference in roentgenographic presentation.

Of the initial 1300 patients reviewed, 60\% had positive cultures, ie, 785 cases had positive cultures of blood, sputum, bronchoalveolar lavage fluid with or without protected brush specimen or positive serology. Streptococcus pneumoniae (154 isolates) and Haemophilus influenzae (147 isolates) predominated overall. The pattern of organisms detected differed in the three groups. In the CAP group, S pneumoniae, H influenzae and Staphylococcus aureus were the predominant organisms. There was also a high incidence of Pseudomonas aeruginosa, a surprising finding. In the HAP group, $S$ aureus and Gram-negative organisms were most common. The NHAP group showed an equal distribution of Gram-positive and Gram-negative organisms (Table 4).

The high incidence of Gram-negative infection in the CAP group was unexpected and had not been previously reported. This phenomenon is mostly due to the finding of $P$ aeruginosa in the CAP group (53 isolates). Although
TABLE 5

Characteristics and clinical course of patients identified with Pseudomonas aeruginosa

\begin{tabular}{|c|c|c|c|}
\hline & CAP & NHAP & HAP \\
\hline \multicolumn{4}{|l|}{ Concurrent medical problem } \\
\hline Cystic fibrosis & 8 & 0 & 0 \\
\hline Bronchiectasis & 2 & 0 & 1 \\
\hline $\begin{array}{l}\text { Hematogenous cancer } \\
\text { (leukemia, lymphoma) }\end{array}$ & 1 & 0 & 2 \\
\hline $\begin{array}{l}\text { Bone marrow transplant } \\
\text { recipient }\end{array}$ & 0 & 0 & 0 \\
\hline Other & 4 & 0 & 5 \\
\hline None & 2 & 1 & 0 \\
\hline \multicolumn{4}{|l|}{ Antibiotics used } \\
\hline $\begin{array}{l}\text { Aminoglycoside + beta- } \\
\text { lactam }\end{array}$ & 14 & 3 & 15 \\
\hline $\begin{array}{l}\text { Aminoglycoside + another } \\
\text { antibiotic (not beta-lactam) }\end{array}$ & 14 & 0 & 10 \\
\hline Other antibiotic regimen & 8 & 1 & 11 \\
\hline Ceftriaxone & 7 & 0 & 6 \\
\hline No antibiotics & 2 & 1 & 0 \\
\hline \multicolumn{4}{|l|}{ Method of detection } \\
\hline Sputum & 47 & 5 & 34 \\
\hline Blood & 3 & 0 & 5 \\
\hline Bronchoalveolar lavage & 1 & 0 & 6 \\
\hline Other & 0 & 0 & 3 \\
\hline $\begin{array}{l}\text { Pseudomonas sole pathogen } \\
\text { detected }\end{array}$ & 43 & 4 & 22 \\
\hline \multicolumn{4}{|l|}{ Outcome } \\
\hline Dead & 11 & 3 & 20 \\
\hline With antibiotics & 11 & 2 & 20 \\
\hline Without antibiotics & 0 & 1 & 0 \\
\hline Alive & 42 & 3 & 21 \\
\hline With antibiotics & 40 & 3 & 21 \\
\hline $\begin{array}{l}\text { With aminoglycoside + } \\
\text { beta-lactam }\end{array}$ & 10 & 2 & 9 \\
\hline With ceftriaxone & 7 & 0 & 2 \\
\hline Without antibiotics & 2 & 0 & 0 \\
\hline
\end{tabular}

CAP Community acquired pneumonia: HAP Hospital acquired pneumo nia: NHAP Nursing home acquired pneumonia

the majority (48) were detected on cultures of sputum and bronchoalveolar lavage fluid, three cases were detected on blood cultures. Ten patients had underlying bronchiectasis or cystic fibrosis and one had an underlying hematogenous malignancy. Although these 11 patients have a higher incidence of colonization with $P$ aeruginosa, they were also at higher risk of developing infection due to $P$ aeruginosa (Table 5).

Two hundred and seven (16\%) of the 1300 patients required ICU admission. Ninety-six (7\%) patients developed complications as defined initially. Complications of pneumonia were highest in the HAP group, occurring in 38 (10\%) of the 378 patients. The complication rate was $6 \%$ in the CAP group and $8 \%$ in the NHAP group (Table 2).

Combination therapy with antimicrobial agents with coverage for Gram-positive and Gram-negative agents was the most common antimicrobial regimen of choice. 
TABLE 6

Pattern of most common initial antimicrobial agents used

\begin{tabular}{lc}
\hline Antimicrobial regimen & Number of patients \\
\hline Non-ceftriaxone & $1081(83 \%)$ \\
Ampicillin & 59 \\
Erythromycin & 44 \\
Clindamycin + cefuroxime/ & 24 \\
ceftazidime & \\
Cefuroxime & 27 \\
Oral erythromycin* & 29 \\
Oral ampicillin/amoxicillin* & 34 \\
Ampicillin/cefazolin + gentamicin & 11 \\
Clindamycin + gentamicin & 11 \\
Erythromycin + cefuroxime & 9 \\
Ceftriaxone & $169(13 \%)$ \\
Ceftriaxone alone & 10 \\
Ceftriaxone + clindamycin/ & 159 \\
erythromycin/other & \\
No antibiotics & $50(4 \%)$ \\
\hline Alther antimicobial regimens
\end{tabular}

'All other antimicrobial regimens were given in the intravenous form unless otherwise stated

Combinations included ceftriaxone with clindamycin or erythromycin (159), clindamycin with cefuroxime or ceftazidime (29), and ampicillin or cefazolin with gentamicin (34). Treatment with single agents was also popular; common monotherapies included ampicillin (59), erythromycin (55) and cefuroxime (27). Fifty (4\%) patients received no antibiotics at all (Table 6).

Thirteen per cent of patients received ceftriaxone either alone (10 of 169) or in combination with other antimicrobials (159 of 169). The most frequent concomitant antibiotics with ceftriaxone were clindamycin and erythromycin. The most common indication for use of ceftriaxone over other antimicrobial regimens was the presence of renal impairment. The dose of ceftriaxone was $1 \mathrm{~g} / 24 \mathrm{~h}$ in about half the patients. High dose ceftriaxone ( 3 to $4 \mathrm{~g} / 24 \mathrm{~h}$ ) was used for those with suspected meningeal infection. Outcomes in those receiving $1 \mathrm{~g} / 24 \mathrm{~h}$ and those receiving $2 \mathrm{~g} / 24 \mathrm{~h}$ were comparable, with mortality of $37 \%$ in both groups. Overall mortality in the group receiving ceftriaxone was $40 \%$ (67 of 169) (Table 7 ). This rate was higher than that of the group receiving other antibiotics, which was, however, a much larger group (1081 versus 169). Differences in adverse reactions and cure rates (Table 8) between the groups may be partially attributable to the fact that patients who received ceftriaxone formed a preselected group, primarily sicker patients and those with renal impairment. Previous studies have shown significantly higher mortality in patients with pneumonia and renal impairment $(7,16)$.

Analysis of patients in whom $P$ aeruginosa was identified revealed that the majority of cases were detected on culture of sputum or bronchoalveolar lavage fluid, although eight of the 100 isolates were from blood
TABLE 7

Outcome of patients treated with different antibiotic regimens

\begin{tabular}{lccc}
\hline Antimicrobial regimen & $\begin{array}{c}\text { Number } \\
\text { dead }\end{array}$ & $\begin{array}{c}\text { Number } \\
\text { alive }\end{array}$ & Total \\
\hline Non-ceftriaxone $(n=1081)$ & 12 & 47 & 59 \\
Ampicillin & 3 & 41 & 44 \\
Erythromycin & 4 & 20 & 24 \\
Clindamycin + & 5 & 22 & 27 \\
$\quad$ cefuroxime/ceftazidime & 6 & 23 & 29 \\
Cefuroxime & 7 & 27 & 34 \\
Oral erythromycin* & 0 & 11 & 11 \\
Oral ampicillin/amoxicillin* & & & \\
Ampicillin/cefazolin + & 6 & 5 & 11 \\
$\quad$ gentamicin & 2 & 7 & 9 \\
Clindamycin + gentamicin & & & \\
Erythromycin + cefuroxime & 2 & 8 & 10 \\
Ceftriaxone $(n=169)$ & 65 & 94 & 159 \\
Ceftriaxone alone & & & \\
Ceftriaxone + clindamycin/ & & & \\
$\quad$ erythromycin/Other & 23 & 27 & 50 \\
\hline No antibiotics $(n=50)$ &
\end{tabular}

-All other antimicrobial regimens were given in the intravenous form unless otherwise stated

cultures (Table 5). Mortality in this subgroup was high (34\%), with higher mortality seen in the HAP and NHAP groups $(50 \%)$. Although overall mortality in the CAP group with positive cultures for $P$ aeruginosa was lower $(20 \%)$ than the group as a whole, the majority (40 of 42) received antibiotics, and 10 received effective antipseudomonal therapy with aminoglycoside plus beta-lactam. Seven received ceftriaxone either alone or in combination with other antimicrobials.

Patient outcome in the different treatment groups was compared (Table 7). Patients who received monotherapy with single agents had better survival rates compared with the group as a whole. Patients receiving erythromycin, either oral or parenteral, had a survival rate of $95 \%$ (52 of 55). Those treated with cefuroxime or ampicillin had survival rates of 81 and $80 \%$, respectively. The worst survival rates were seen in patients treated with clindamycin and gentamycin (45\%) and in those receiving no therapy at all (54\%).

In all, $959(73 \%)$ patients were deemed to have improved or been cured at the time of discharge. Twenty-one (1.5\%) patients discharged themselves against medical advice and were presumed to have survived. Three hundred and twenty (25\%) patients died during admission to hospital; of these, 165 deaths could be attributed to pneumonia on review of the death certificate.

\section{DISCUSSION}

Our five-year review of all patients discharged with a diagnosis of pneumonia from hospital from April 1987 to March 1992 contains the most recent comprehensive data available. Data from the initial 1300 of 1782 cases 
TABLE 8

Outcome and adverse drug reaction in the different treatment groups

\begin{tabular}{lcccccc}
\hline Treatment group & Adverse reactions* & Cured & Improved & Dead & Self-discharge & Total \\
\hline Ceftriaxone $(1 \mathrm{~g} / 24 \mathrm{~h})$ & $11(12 \%)^{\dagger}$ & $13(14 \%)$ & $42(46 \%)$ & $34(37 \%)$ & $1(2 \%)$ & 91 \\
Ceftriaxone $(2 \mathrm{~g} / 24 \mathrm{~h})$ & $5(7 \%)^{\dagger}$ & $13(19 \%)$ & $29(43 \%)$ & $25(37 \%)$ & 0 & 07 \\
Ceftriaxone $(3 \mathrm{~g} / 24 \mathrm{~h})$ & $1(25 \%)$ & 0 & 0 & $4(100 \%)$ & 0 & 0 \\
Ceftriaxone $(4 \mathrm{~g} / 24 \mathrm{~h})$ & 0 & $1(25 \%)$ & $1(25 \%)$ & $2(50 \%)$ & 4 \\
Other antibiotics & $64(4 \%)$ & $241(20 \%)$ & $591(54 \%)$ & $230(22 \%)$ & $19(1 \%)$ & 1081 \\
No antibiotics & $\mathrm{N} / \mathrm{A}$ & $9(16 \%)$ & $18(36 \%)$ & $23(46 \%)$ & $1(2 \%)$ & 50 \\
Total & $81(6 \%)$ & $278(21 \%)$ & $681(52 \%)$ & $320(25 \%)$ & $21(1.5 \%)$ & 1300 \\
\hline
\end{tabular}

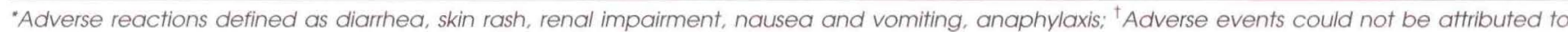
ceftriaxone alone

of pneumonia continue to support previous suggestions that pneumonia remains a serious illness with significant morbidity and mortality. Pneumonia accounted for $2.6 \%$ of all discharges from our hospital during this period. As a group, these patients tended to be older and were ill, with $97 \%$ having at least one comorbid illness. Previous authors $(3,4,6,8-10)$ have reported a lower incidence of comorbid illness in patients hospitalized with pneumonia. The current data are likely a reflection of the trend to treat more patients in an ambulatory setting. Since studies have shown that patients with pneumonia and concurrent illness have more severe disease $(8,9)$, it is reasonable to assume that those admitted to hospital represent the sicker end of the spectrum.

As in previous reports $(3-10,12,16), S$ pneumoniae is the predominant organism in all groups with pneumonia. $H$ influenzae and $S$ aureas also continue to be important pathogens. The high incidence of $P$ aeruginosa isolated from the CAP group is surprising and unexpected. This finding has not been previously described. In the two most recently published studies $(4,5)$, P aeruginosa was an uncommon cause of CAP. The existence of a burn unit in our centre would favour more Pseudomonas species in the nosocomial group but cannot readily explain the CAP population. Three of the 53 isolates were definitely pathogens, having been detected on blood culture. Eleven of the 53 cases had underlying conditions (bronchiectasis, cystic fibrosis or hematogenous cancer) that would increase the incidence of colonization but, at the same time, increase the risk of infection with $P$ aeruginosa. Although it is difficult to ascertain the pathogenicity of a positive $P$ aeruginosa culture in a retrospective study, 97 of 100 patients were treated with antibiotics, of whom a third received adequate $P$ aeruginosa coverage with aminoglycoside plus beta-lactam. Survival in the CAP group with $P$ aeruginosa was not different from the overall survival $(80 \%$ versus $75 \%)$. With a trend towards increased ambulatory patient management, those with CAP requiring hospitalization over the past several years are likely sicker and have more comorbid illness than those managed as out-patients. Our data likely reflect a change in the pattern of pathogens affecting this subpopulation with CAP.
Although a higher incidence of Gram-negative organisms is found in NHAP and HAP, $S$ aureus is also a significant causative organism in these two subgroups. These findings are consistent with other reports of nosocomial pneumonia (17-24).

The different mortality rates seen in association with the different antimicrobial regimens likely represent the severity of illness rather than the efficacy of the different treatment modalities. It is certainly reasonable to assume that patients treated with erythromycin, cefuroxime or ampicillin alone represented those who were clinically more stable, whereas those receiving combination therapy, particular combinations that included anaerobic and/or Gram-negative coverage, were more ill. These were likely patients with risk factors for aspiration or having serious comorbid disease.

Most reports of microbiological investigations in the management of pneumonia have found a utility in the range of $50 \%$. Although we have not improved the yield of our investigations to identify the offending pathogen, routine cultures of sputum, blood in all patients requiring hospitalization and in select cases, bronchoalveolar lavage fluid, serological specimens and pleural fluid should be sent. Because antimicrobial agents are begun empirically in the majority of cases, these relatively inexpensive and simple investigations may help to narrow the spectrum of antibiotics used and improve the precision of management. Furthermore, knowledge of culture and sensitivities may guide appropriate choice of oral step-down therapy.

Mortality directly attributed to pneumonia was $13 \%$ (165 of 1300). Overall mortality in our study is $25 \%$ and appears unchanged from previous reports. However, this population is sicker. They have more concomitant illnesses than previous groups that have been described. Cases of pneumonia managed in the out-patient setting are logistically difficult to study but one can logically assume that these patients have a better outcome than their counterparts who require hospitalization. In this study, mortality is similar to that described in previous studies in which the patient populations were less ill (3-10). Therefore, it is possible that our current ability to manage this persistent illness is improving. 
Given the pattern of causative agents seen in our study, it appears that monotherapy with ampicillin, erythromycin or cefuroxime in the relatively well CAP group is appropriate. For the sicker CAP and for the NHAP and HAP groups, combination therapy with a beta-lactam and a Gram-negative or anaerobic agent or ceftriaxone are appropriate initial agents. A ceftriaxone dose of $1 \mathrm{~g} / 24 \mathrm{~h}$ is comparable with the higher dose of $2 \mathrm{~g} /$ day and should be used. Erythromycin is particularly appropriate as an initial agent in cases where $M$ pneumoniae or Legionella pneumophila is suspected or where it is more prevalent.

Although our study is retrospective and therefore has many of the problems associated with these types of studies, its strength resides in the large number of

ACKNOWLEDGEMENTS: This work was made possible in part by a research grant from Roche Canada Ltd. The authors thank the staff of the Medical Records Department of the Wellesley Hospital for chart retrieval.

\section{REFERENCES}

1. Garibaldi RA. Epidemiology of community acquired respiratory tract infections in adults. Am J Med 1985;78(Suppl 6B):32-7.

2. Hospitalizations for the leading causes of death among the elderly - United States, 1987. MMWR 1990;39:777-85.

3. Bates JH, Campbell D, Barron AL, et al. Microbial etiology of acute pneumonia in hospitalized patients. Chest 1992;101:1005-12.

4. Fang G-D, Fine M, Orloff J, et al. New and emerging etiologies for community acquired pneumonia with implications for therapy. Medicine 1990;69:307-16.

5. Marrie TJ, Durant H, Yates L. Community acquired pneumonia requiring hospitalization: A 5-year prospective study. Rev Infect Dis 1989;1 1:586-99.

6. Woodhead MA, Macfarlane JT. Prospective study of etiology and outcome of pneumonia in the community. Lancet 1987;i:671-4.

7. Ortqvist A, Sterner G, Nisson JA. Severe community acquired pneumonia: Factors influencing need of intensive care treatment and prognosis. Scand J Infect Dis 1985; 17:377-86.

8. Torres A, Serra-Batlles J, Ferrer A, et al. Severe community-acquired pneumonia: Epidemiology and prognostic factors. Am Rev Respir Dis 1991;144:312-8.

9. Pachon J, Prados MD, Capote F, Cuello JA, Garnacho J, Verano A. Severe community-acquired pneumonia: Etiology, prognosis and treatment. Am Rev Respir Dis 1990; 142:369-73.

10. Venkatesan P, Gladman J, Marfalane JT, et al. A hospital study of community acquired pneumonia in the elderly. Thorax 1990;45:254-8.

11. Sorensen J, Cederholm I, Carlsson C. Pneumonia: A deadly disease despite intensive care treatment. Scand J Infect Dis 1986; 18:329-35.

12. Woodhead MA, Marfarlane JT, Rodgers FG, Laverick A, Pilkington R, Macrae AD. Aetiology and outcome of severe community acquired pneumonia. J Infect 1985; 10:204-10. patients and its current setting. The most recent large scale published reports $(4,5)$ of CAP ended in 1987 and had considerably fewer patients than the current study, which began in 1987.

It is important to update periodically our knowledge of the epidemiology and pathogenesis of pneumonia for several reasons. The emergence of resistant organisms and the rapid development of new antimicrobial agents can quickly outdate our current management. In addition, a rational approach to choice of empirical agents used requires up to date knowledge of the pattern of offending organisms and the population at risk. This study supports our current approach to the management and treatment of CAP. NHAP and HAP.

13. American Thoracic Society. Guidelines for the initial management of adults with community acquired pneumonia: Diagnosis, assessment of severity and initial antimicrobial therapy. Am Rev Respir Dis 1993; 148:1418-26.

14. Mandell LA, Niederman M, The Canadian Community Acquired Pneumonia Consensus Conference Group. Antimicrobial treatment of community acquired pneumonia in adults: A conference report. Can J Infect Dis 1993:4:25-8.

15. Rodnick JE, Gude JK. Diagnosis and antibiotic treatment of community acquired pneumonia. West J Med 1991;154:405-9.

16. Felman C, Kallenbach JM, Levy H, et al. Community acquired pneumonia of diverse aetiology: Prognostic features in patients admitted to an intensive care unit and a 'severity of illness' score. Intensive Care Med 1989;15:302-7.

17. Rello J, Quintana E, Ausina V, et al. Incidence, etiology and outcome of pneumonia in mechanically ventilated patients. Chest 1991:100:439-44.

18. Jimenez P, Torres A, Rodriguez-Roisin R, et al. Incidence and etiology of pneumonia acquired during mechanical ventilation. Crit Care Med 1989;17:882-5.

19. Potgieter PD, Hammond JMJ. Etiology and diagnosis of pneumonia requiring ICU admission. Chest 1992;101:199-203.

20. Rodriguez de Castro F, Violan JS, Capuz BL, Luna JC, Rodriguez BG, Alonso JLM. Reliability of the bronchoscopic protected catheter brush in the diagnosis of pneumonia in mechanically ventilated patients. Crit Care Med 1991;19:171-5.

21. Ruis-Santana S, Jimenez AG, Esteban A, et al. ICU pneumonias: A multi-institutional study. Crit Care Med 1987:15:930-2.

22. Fagon J-Y, Chastre J, Domart Y, et al. Nosocomial pneumonia in patients receiving continuous mechanical ventilation. Am Rev Respir Dis 1989;139:877-84.

23. Pham LH, Brun-Buisson C, Legrand P, et al. Diagnosis of nosocomial pneumonia in mechanically ventilated patients. Am Rev Respir Dis 1991;143:1055-61.

24. Chastre J. Prospective evaluation of the protected specimen brush for the diagnosis of pulmonary infections in ventilated patients. Am Rev Respir Dis 1984;130:924-9. 


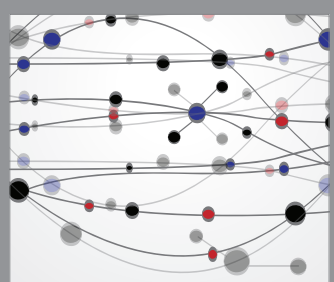

The Scientific World Journal
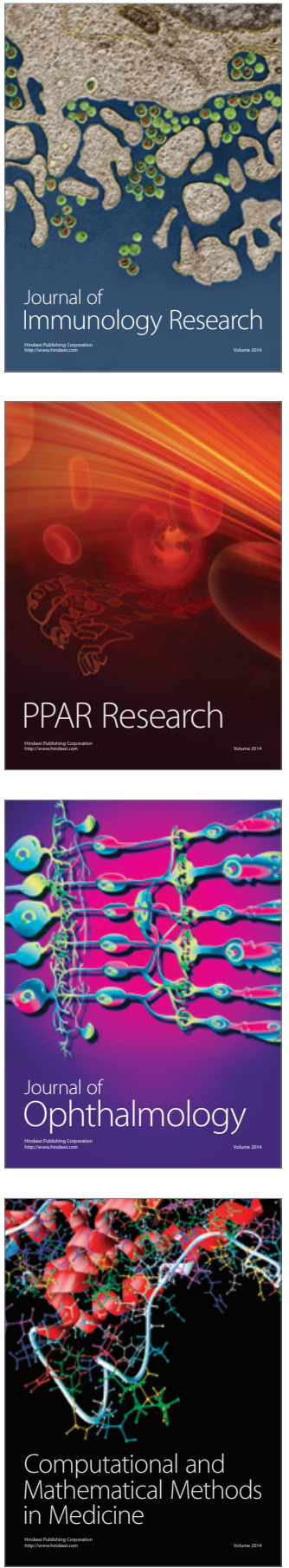

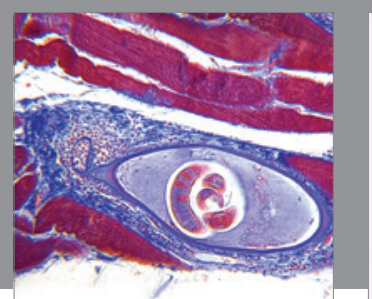

Gastroenterology Research and Practice

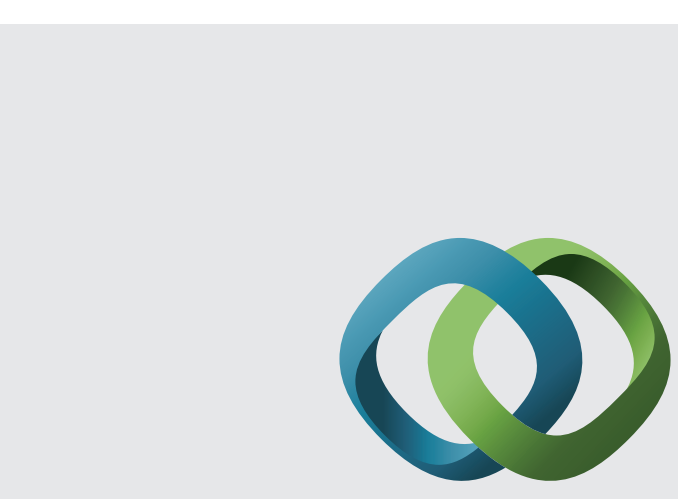

\section{Hindawi}

Submit your manuscripts at

http://www.hindawi.com
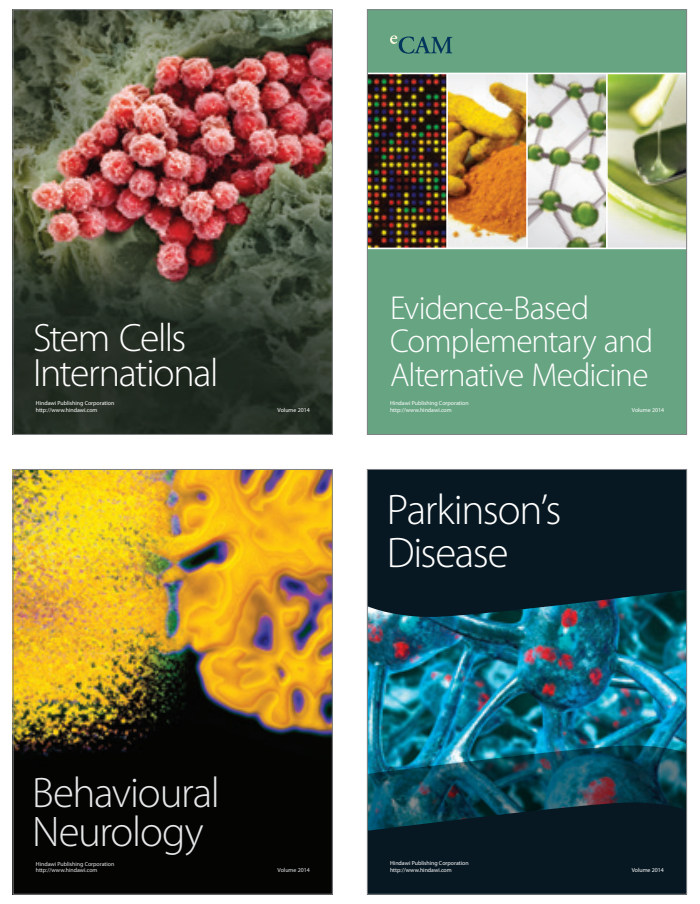
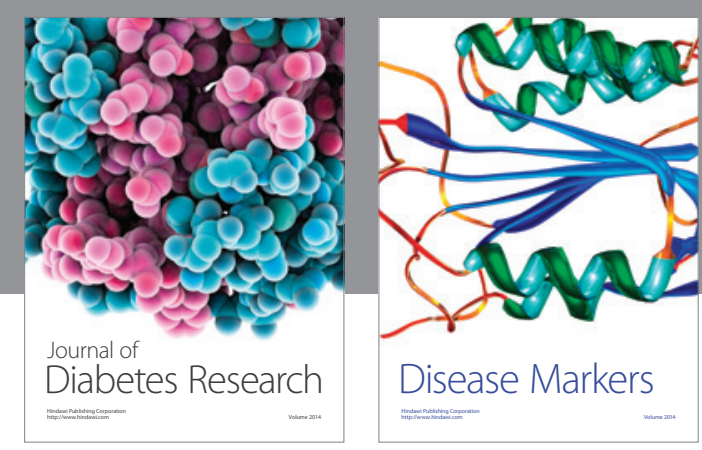

Disease Markers
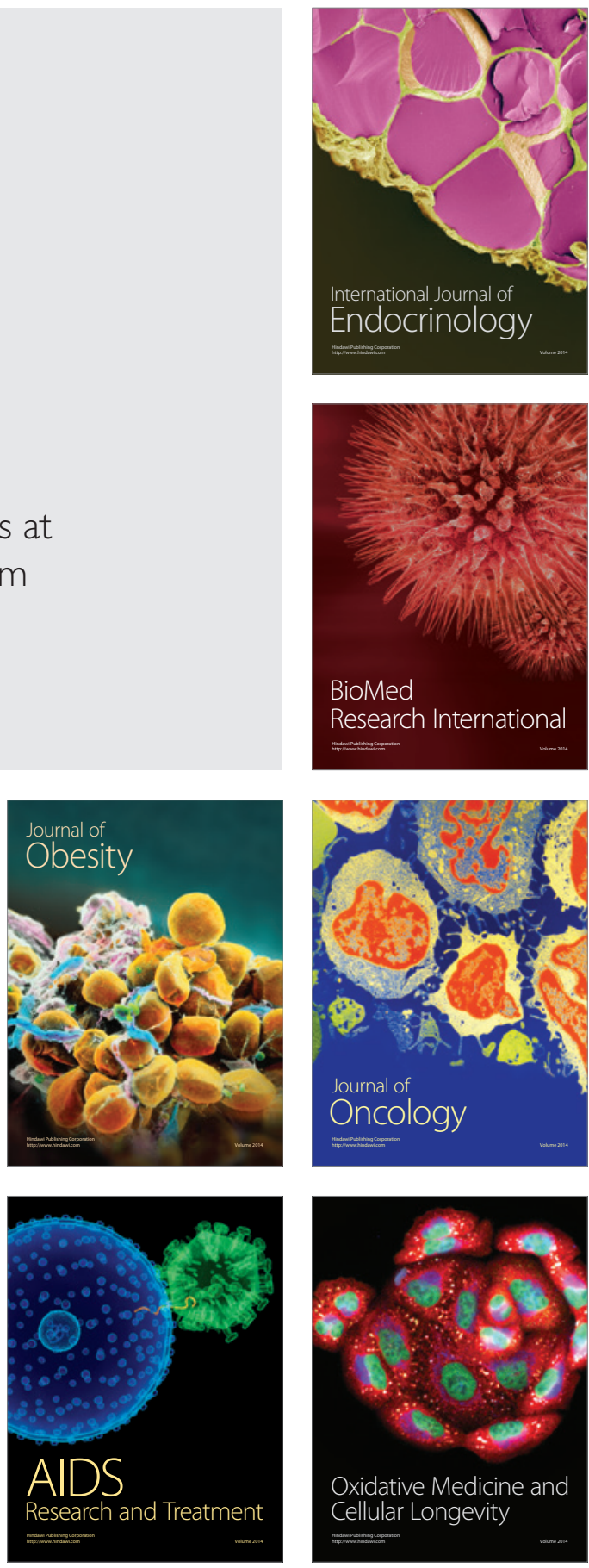